\title{
Herbicide-tolerant endophytic bacteria of rice plants as the biopriming agents for fertility recovery and disease suppression of unhealthy rice seeds
}

\author{
Chakrapong Rangjaroen ${ }^{1}$, Saisamorn Lumyong ${ }^{2,3,4}$, William T. Sloan ${ }^{5}$ and Rungroch Sungthong ${ }^{5^{*}}$ (D)
}

\begin{abstract}
Background: Dirty panicle disease (DPD) caused by several fungal phytopathogens results in damage and depreciation of rice seeds. Unhealthy rice seeds with DPD are potent reservoirs of pathogens and unable to be used as seed stock as they can spread the disease in the paddy fields leading to the severe loss of rice yield and quality. In this study, we aim to search for beneficial endophytes of commercially cultivated rice plants and utilize them as biostimulants in seed biopriming for fertility recovery and disease suppression of unhealthy rice seeds.

Results: Forty-three bacterial endophytes were isolated from rice plants grown in the herbicide-treated paddy fields. Five isolates of these endophytes belonging to the genus Bacillus show excellent antifungal activity against fungal pathogens of DPD. Based on germination tests, biopriming unhealthy rice seeds by soaking in bacterial suspensions for 9 or $12 \mathrm{~h}$ was optimal as evidenced by the lowest disease incidence and longer shoot and root lengths of seedlings germinated, compared with controls made of non-treated or hydroprimed healthy and unhealthy seeds. Pot experiments were carried out to evaluate the impact of seed biopriming, in which the percentage of healthy rice yield produced by rice plants emerging from bioprimed seeds was not significantly different, compared to the controls originating respectively from non-treated healthy seeds and chemical fungicidetreated unhealthy seeds.

Conclusion: Biopriming of unhealthy rice seeds with herbicide-tolerant endophytic bacteria could recover seed fertility and protect the full life cycle of emerging rice plants from fungal pests. With our findings, seed biopriming is a straightforward approach that farmers can apply to recover unhealthy rice seed stock, which enables them to reduce the cost and use of agrochemicals in the commercial production of rice and to promote green technology in sustainable agriculture.
\end{abstract}

Keywords: Bacterial endophytes, Phytopathogenic fungi, Dirty panicle disease, Rice, Seed stock, Seed biopriming, Herbicide-tolerant bacteria

\section{Background}

Thai jasmine rice (Oryza sativa L. cv. KDML105) is a commercially important crop in Thailand, and its recent export value rises to $1225 \$ \mathrm{t}^{-1}$ [1]. The quality of rice grains is the critical factor that determines the commercial value of this cereal product. Some of the high-

\footnotetext{
* Correspondence: rungroch.sungthong@glasgow.ac.uk

${ }^{5}$ Infrastructure and Environment Research Division, School of Engineering,

University of Glasgow, Glasgow G12 8LT, UK

Full list of author information is available at the end of the article
}

quality, healthy-looking rice seeds are kept and used as seed stock for subsequent cultivation. Rice seeds that are unhealthy by having abnormal changes and or lesions are sorted out, and depending upon their quality, these unhealthy seeds may be used as animal feed or left for destruction. The physical appearances of unhealthy rice seeds are the symptoms of dirty panicle disease (DPD) or grain discoloration, which is a typical disease of rice seeds caused by several phytopathogenic fungi [2]. Hence, unhealthy rice seeds are considered the potent

(c) The Author(s). 2019 Open Access This article is distributed under the terms of the Creative Commons Attribution 4.0 International License (http://creativecommons.org/licenses/by/4.0/), which permits unrestricted use, distribution, and 
reservoirs of phytopathogens and unable to be used as seed stock because they can spread the disease in the paddy field leading to the severe loss of rice yield and quality.

It is hard to detect and prevent DPD earlier, as the causative agents are nonspecific, and the physical symptoms occur on mature rice grains at the harvesting phase. When DPD occur during rice production, it is often too late to recover the quality of rice yields. Improper storage of healthy-looking rice seeds can also induce DPD because the surface of rice seeds house more than 100 species of fungi and numerous of them are common pathogens of rice [3, 4]. In 2013, massive rice yields produced in Thailand became invaded with fungal pests during storage [5], while a lot of these rice seeds had symptoms of DPD. This damage did not only engender an adverse impact on the country's agroeconomy but also the profits of farmers. A strategy to prevent the occurrence of DPD is to use good quality seed stock for cultivation of rice. In order to maintain the quality of seed stock before use in rice cultivation, seed treatment is often performed.

Although many approaches are available in the market for seed treatment [6,7], most are carried out for maintaining healthy seeds and protecting them from pest invasion during storage. Unfortunately, when a little sign of DPD observed on rice seeds, they have been treated as unhealthy seeds and become agricultural waste. Recovery of these unhealthy rice seeds for being used as seed stock with acceptable quality would be a challenging way to add value to them and further reduce the cost in rice cultivation. Hitherto, the optimal treatment for fertility recovery and disease suppression of unhealthy rice seeds is still unknown. Chemical treatment of these unhealthy seeds with pesticides may be an approach for rapid disease suppression. However, using pesticide-treated seeds for cultivation may result in some environmental concerns, as the residues of pesticides may endanger the beneficial plantassociated microbes and persist in agroecosystem or accumulate into the ecological food web [6, 8]. Moreover, pesticide-contaminated crops can depreciate their quality and adversely affect consumers' health $[9,10]$.

Seed biopriming could be a strategy of green technologies for seed treatment in promoting sustainable agriculture with the aim of reducing the use of agrochemicals in crop production [11-13]. This biological technique employs beneficial microbes possessing plant growthpromoting (PGP) potentials, by simply saturating seeds into an active microbial suspension for an optimal duration followed by seed moisture monitoring before use as seed stock. The method allows microbial cells to colonize the outer parts of seeds, where the synergistic interactions take place as microbes utilize grains' nutritive exudates for their proliferation and biosynthesis of biocontrol agents to protect seeds from pests [13, 14]. Numerous PGP bacteria have been used as bioactive agents for biopriming [11-14]. These bacteria are often isolated from plant-associated sources, like PGP rhizobacteria that live in the plant rhizosphere. Another technical advantage of using PGP bacteria in biopriming is that they are fast growing and easy for harvesting and preparing as microbial suspension. By the way, the efficiency of seed biopriming for the restoration of unhealthy rice seeds is yet to be investigated.

It is conceivable that many steps in rice production require beneficial plant-microbe interactions to promote growth and productivity of rice plants. Many studies revealed that several rice endophytic bacteria are promising growth promoters of rice plant [15-18]. These endophytes live in the interiors of rice and do not form any disease. Moreover, they can either promote rice growth or protect rice from invasive phytopathogens for the entire period of rice development and production. However, in commercial rice cultivation, it is hard to avoid using agrochemicals in order to maintain high rice yield $[16,19]$. For instance, in the paddy field, weeds are unwanted as they grow in competition with rice plants, by stealing soil nutrients and water [20]. Weeds can also be reservoirs of pests and phytopathogens that damage rice plants and yields [21]. Hence, herbicides are often applied in the paddy field to stop growth of weeds. With these reasons, endophytic PGP bacteria with capability to tolerate herbicides commonly used in rice production would potentially be the ideal biopriming agents.

In this study, we aim to develop a straightforward protocol for biopriming of unhealthy rice seeds using endophytic PGP bacteria of rice plants. The virulence level of DPD of stored rice seed stock was classified. Rice seeds with severe DPD served as the sources for isolation of fungal pathogens. Rice plants grown commercially in fields treated with different herbicides were used for isolation of herbicide-tolerant endophytic bacteria. Antifungal activity of the isolated endophytic bacteria was screened. Biopriming of unhealthy rice seeds using the best antifungal bacteria was developed and assessed for its effectiveness in fertility recovery and disease suppression of the rice seeds. The assessments were carried out from germination to harvesting of rice yields.

\section{Results}

\section{Fungal pathogens of DPD}

Sixty-two fungi were isolated from rice seeds showing DPD, six of which exhibited virulent pathogenicity (Table 1). These pathogenic fungi were identified as the members of the genera Bipolaris, Curvularia, Nigrospora, and Fusarium, supported by $97-100 \%$ similarity of their ITS gene sequences compared to those available in public databases (Table 1 and Fig. 1). Two isolates 
Table 1 Pathogenic fungi of Thai jasmine rice seeds ${ }^{a}$ showing dirty panicle disease

\begin{tabular}{|c|c|c|}
\hline Pathogenic fungi ${ }^{b}$ & Closest phylogenetic species $^{c}$ & $\%$ Identity \\
\hline KPS3 (MG309751) & Bipolaris panici-miliacei CBS $199.29^{\top}$ (KJ909773) & 100 \\
\hline KPS5 (MG309754) & B. panici-miliacei CBS 199.29 (KJ909773) & 100 \\
\hline KPS41 (MG309752) & Curvularia soli CBS 222.96 (KY905679) & 99 \\
\hline KPS45 (MG309753) & Nigrospora camelliae-sinensis CGMCC3.18125 (KX985986) & 98 \\
\hline KPS91 (MG309755) & Fusarium chlamydosporum var. fuscum CBS $635.76^{\top}$ (AY213655) & 99 \\
\hline KPS102 (MG309756) & Curvularia pseudobrachyspora CPC28808 (MF490819) & 97 \\
\hline
\end{tabular}

${ }^{a}$ The plant specimen was deposited for further reference at CMUB Herbarium with the code, CMUB39907. ${ }^{b}$ The fungal ITS gene sequences were deposited in GenBank with accession numbers in parentheses. ${ }^{\circ}$ The $\%$ identity refers to the similarity percentage of the gene sequence of each fungal isolate compared to its closest phylogenetic species (GenBank accession number)

(KPS3 and KPS5) belonged to the genus Bipolaris, and both were closely related to Bipolaris panici-miliacei CBS $199.29^{\mathrm{T}}$ supported by $100 \%$ similarity of the gene sequences. The other two isolates, KPS41 and KPS102, belonged to the genus Curvularia, and each of them was closely related to Curvularia soli CBS $222.96^{\mathrm{T}}$ and Curvularia pseudobrachyspora CPC $28808^{\mathrm{T}}$ supported by 99 and $97 \%$ similarity of the gene sequences, respectively.

\section{Herbicide-tolerant endophytic bacteria of rice and their antifungal activity}

Forty-three herbicide-tolerant bacteria were isolated from the interiors of different rice cultivars growing in the herbicide-treated paddy fields (Table 2). O. sativa L. var. indica cv. RD41 housed the highest number of bacteria (13 isolates), while the other sources, O. sativa L. var. indica $\mathrm{cv}$. Pathumthani 1 grown at different field locations and treated with different herbicides, each resulted in 10 bacterial isolates. Root tissues of any rice cultivars housed a relatively higher number of bacteria (4-7 isolates). All bacteria were tested for their antifungal activity against a set of virulent fungi causing DPD of rice seeds, and five of which showed excellent antifungal activity (Fig. 2). These bacteria were identified as the members of the genus $\mathrm{Ba}$ cillus supported by $99-100 \%$ similarity of their $16 \mathrm{~S}$ rRNA gene sequences compared to those available in public databases (Table 3 and Fig. 3). Three isolates (CPS003, CZR007, and CZL003) were closely related to Bacillus

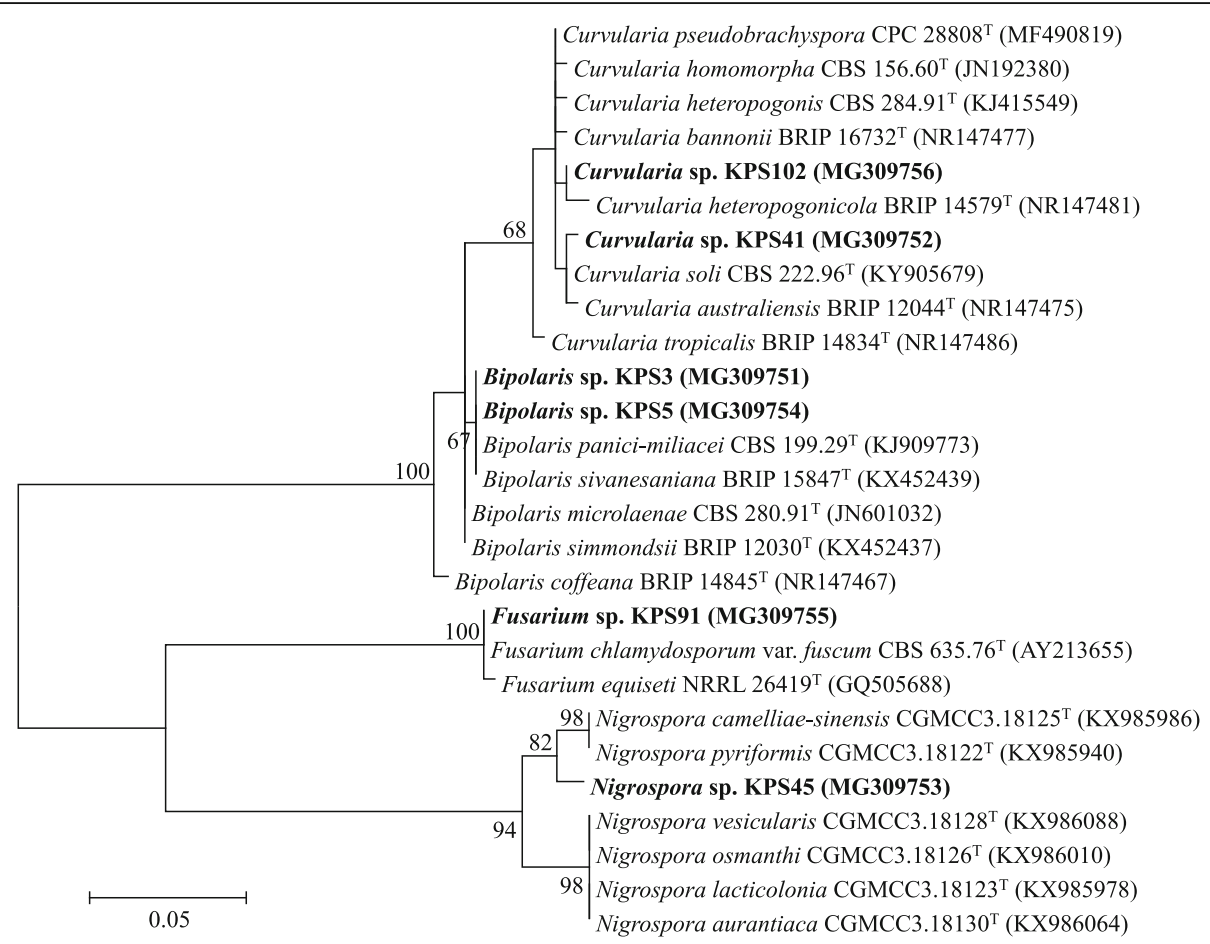

Fig. 1 Unrooted phylogenetic tree of ITS gene sequences of the virulent pathogenic fungi isolated from rice seeds showing dirty panicle disease. The fungal isolates are in bold, and their GenBank accession numbers are in parentheses. The tree was constructed using the MaximumLikelihood algorithm. Bootstrap values (based on 1000 replications) of $>60 \%$ are at the tree's nodes, and scale bar represents $5 \%$ dissimilarity 
Table 2 Source information of herbicide-tolerant endophytic bacteria of field-growing rice

\begin{tabular}{|c|c|c|c|c|c|c|c|}
\hline \multirow[t]{2}{*}{ Rice cultivar } & \multirow[t]{2}{*}{ Field location } & \multicolumn{2}{|c|}{ Herbicide concentration } & \multirow[t]{2}{*}{$\begin{array}{l}\text { Plant age } \\
(\text { day })^{b}\end{array}$} & \multicolumn{3}{|c|}{$\begin{array}{l}\text { Herbicide-tolerant endophytic } \\
\text { bacteria (number of isolate) }\end{array}$} \\
\hline & & $\begin{array}{l}\text { Field application } \\
\text { (active ingredient) }^{a}\end{array}$ & $\begin{array}{l}\text { Isolation medium } \\
\left(\mathrm{L}^{-1}\right)\end{array}$ & & Root & Stem & Leaf \\
\hline \multirow[t]{3}{*}{$\begin{array}{l}\text { Oryza sativa L. var. } \\
\text { indica } \mathrm{Cv} \text {. Pathumthani } 1\end{array}$} & \multirow[t]{2}{*}{$\begin{array}{l}\text { Sam Chuk District, } \\
\text { Suphan Buri } \\
\text { Province, Thailand }\end{array}$} & $\begin{array}{l}3 \mathrm{~g} \text { of } 10 \%(\mathrm{w} / \mathrm{v}) \\
\text { Metsulfuron-methyl } \\
+10 \%(\mathrm{w} / \mathrm{v}) \\
\text { Chlorimuron-ethyl } \\
\text { in } 60 \mathrm{~L} \text { of water }\end{array}$ & $\begin{array}{l}5 \text { mg Metsulfuron- } \\
\text { methyl and } 5 \text { mg } \\
\text { Chlorimuron-ethyl }\end{array}$ & $13^{c}$ & $\begin{array}{l}\text { MCR001 - } \\
\text { MCR004 (4) }\end{array}$ & $\begin{array}{l}\text { MCS005 - } \\
\text { MCS007 (3) }\end{array}$ & $\begin{array}{l}\text { MCL008 - } \\
\text { MCL010 (3) }\end{array}$ \\
\hline & & $\begin{array}{l}40 \mathrm{~mL} \text { of } 10 \%(\mathrm{w} / \mathrm{v}) \\
\text { Bispyribac-sodium } \\
\text { in } 60 \mathrm{~L} \text { of water }\end{array}$ & $\begin{array}{l}0.07 \mathrm{~mL} \text { Bispyribac- } \\
\text { sodium }\end{array}$ & $16^{\mathrm{d}}$ & $\begin{array}{l}\text { BSR001 - } \\
\text { BSR005 (5) }\end{array}$ & BSS006 (1) & $\begin{array}{l}\text { BSL007 - } \\
\text { BSL010 (4) }\end{array}$ \\
\hline & $\begin{array}{l}\text { Si Prachan District, } \\
\text { Suphan Buri } \\
\text { Province, Thailand }\end{array}$ & $\begin{array}{l}100 \mathrm{~mL} \text { of } 12 \%(\mathrm{w} / \mathrm{v}) \\
\text { Clomazone }+27 \% \\
(\mathrm{w} / \mathrm{v}) \text { Propanil in } \\
20 \mathrm{~L} \text { of water }\end{array}$ & $\begin{array}{l}0.64 \mathrm{~mL} \text { Clomazone } \\
\text { and } 1.44 \mathrm{~mL} \text { Propanil }\end{array}$ & $15^{e}$ & $\begin{array}{l}\text { CPR005 - } \\
\text { CPR007 (3) }\end{array}$ & $\begin{array}{l}\text { CPSO01 - } \\
\text { CPSO04 (4) }\end{array}$ & $\begin{array}{l}\text { CPL008 - } \\
\text { CPL010 (3) }\end{array}$ \\
\hline $\begin{array}{l}\text { Oryza sativa L. var. } \\
\text { indica } \mathrm{cv} \text {. RD41 }\end{array}$ & $\begin{array}{l}\text { Sai Noi District, } \\
\text { Nonthaburi Province, } \\
\text { Thailand }\end{array}$ & $\begin{array}{l}200 \mathrm{~mL} \text { of } 48 \%(\mathrm{w} / \mathrm{v}) \\
\text { Clomazone in } 60 \mathrm{~L} \\
\text { of water }\end{array}$ & $1.60 \mathrm{~mL}$ Clomazone & $13^{f}$ & $\begin{array}{l}\text { CZR007 - } \\
\text { CZR013 (7) }\end{array}$ & $\begin{array}{l}\text { CZSO004 - } \\
\text { CZSO06 (3) }\end{array}$ & $\begin{array}{l}\text { CZL001 - } \\
\text { CZL003 (3) }\end{array}$ \\
\hline
\end{tabular}

${ }^{a}$ The herbicides were applied by spraying onto the field after sowing for $13-16$ days and the rice plants were collected from the field 3 days afterward. ${ }^{b}$ Plant specimens were deposited for further references at CMUB Herbarium with the following codes, ${ }^{c} \mathrm{CMUB} 39903,{ }^{d} \mathrm{CMUB} 39904,{ }^{e} \mathrm{CMUB} 39905$, and ${ }^{f} \mathrm{CMUB} 39906$

subtilis subsp. subtilis DSM $10^{\mathrm{T}}$ supported by $99 \%$ similarity of the gene sequences. Each of the other two isolates (CZS004 and CZS006) was closely related to Bacillus altiludinis $41 \mathrm{KF}^{2} \mathrm{~b}^{\mathrm{T}}$ and Bacillus kochii $\mathrm{WCC}^{2} 582^{\mathrm{T}}$ supported by 100 and $99 \%$ similarity of the gene sequences, respectively. Bacillus sp. CZR007 revealed the highest antifungal activity (nearly 100\%) against Bipolaris sp. KPS5 and Curvularia sp. KPS102 (Figs. 2 and 4).

\section{Fertility and quality of unhealthy rice seed stocks after biopriming}

The biopriming potentials of unhealthy rice seeds with selected bacteria were primarily assessed at the germination and seedling growth phases using germination percentage (GP), germination index (GI), mean germination time (MGT), disease incidence (DI), and the length of seedlings' roots and shoots as the indicators (Fig. 5). GPs

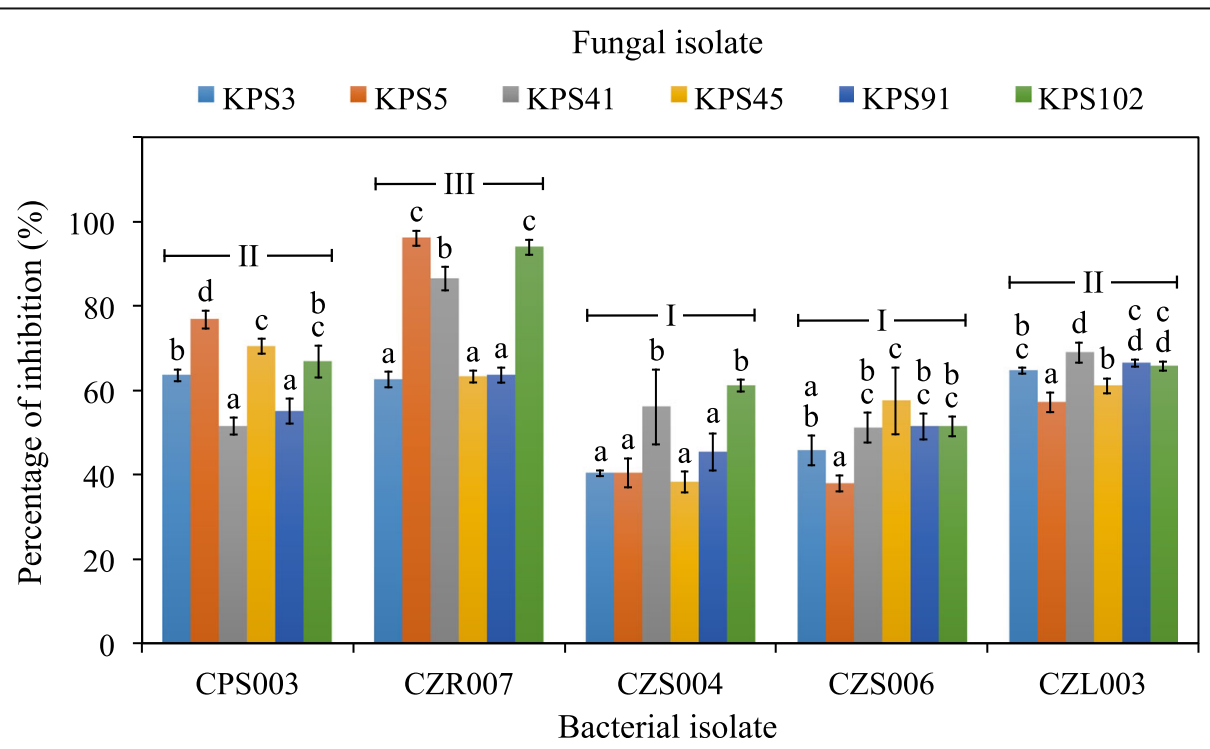

Fig. 2 Antifungal activity of herbicide-tolerant endophytic bacteria of field-growing rice. These bacterial isolates (CPS003, CZR007, CZS004, CZS006, and CZL003) showed the best antifungal activity against the virulent pathogenic fungi of rice seeds showing dirty panicle disease (KPS3, KPS5, KPS41, KPS45, KPS91, and KPS102). The percentages of inhibition were calculated using the data derived from the dual culture assay of the test bacteria and fungi. Error bars are mean values \pm SDs of four replicates per assay. The statistical differences at $P=0.05$ of means are indicated with small case letters for each test bacterium against different test fungi and with the Roman numbers for the comparison between different bacterial isolates regardless of the distinct fungi tested. All statistical analyses were conducted using one-way ANOVA with Tukey's post hoc test 
Table 3 Herbicide-tolerant endophytic bacteria of field-growing rice

\begin{tabular}{|c|c|c|}
\hline Herbicide-resistant endophytic bacteria $^{a}$ & Closest phylogenetic species $^{b}$ & $\%$ Identity $^{t}$ \\
\hline CPS003 (MG309712) & Bacillus subtilis subsp. subtilis DSM $10^{\top}$ (KI812207) & 99 \\
\hline CZR007 (MG309714) & B. subtilis subsp. subtilis DSM $10^{\top}$ (KJ812207) & 99 \\
\hline CZS004 (MG309715) & Bacillus altitudinis $41 \mathrm{KF} 2 \mathrm{~b}^{\top}$ (AJ831842) & 100 \\
\hline CZS006 (MG309716) & Bacillus kochii WCC4582' (FN995265) & 99 \\
\hline CZL003 (MG309713) & B. subtilis subsp. subtilis DSM $10^{\top}$ (KJ812207) & 99 \\
\hline
\end{tabular}

${ }^{a}$ These herbicide-resistant endophytic bacteria showed the best antifungal activity against pathogenic fungi of dirty panicle disease, and their16S rRNA gene sequences were deposited in GenBank with accession numbers in parentheses. ${ }^{b}$ The $\%$ identity refers to the similarity percentage of the gene sequence of each bacterial isolate compared to its closest phylogenetic species (GenBank accession number)

of non-treated healthy and unhealthy seeds were not statistically different and showed significantly lower $(\sim 65-$ $70 \%)$ compared to those of any primed seeds $(\sim 85-$ 90\%) (Fig. 5-a). There was no significant difference between GPs of any primed seeds. However, unhealthy seeds hydropriming for 3 and $15 \mathrm{~h}$ showed slightly lower GPs. GI also exhibited a similar trend of results, while any seeds priming for $3 \mathrm{~h}$ revealed a slightly lower GI (Fig. 5-b). MGTs of non-treated healthy and unhealthy seeds were slowest ( $\sim 4$ days), while any seeds priming for 3 and $15 \mathrm{~h}$ exhibited slightly faster (Fig. 5-c). DI of non-treated unhealthy seeds was highest (Fig. 5-d). Among any primed seeds, DI was relatively lower when priming for 6,9 , and $12 \mathrm{~h}$. The lengths of seedlings' roots (Fig. 5-e) and shoots (Fig. 5-f) were longest when such seedlings emerging from unhealthy seeds biopriming for 9 and $12 \mathrm{~h}$. These results suggested that the optimal priming duration (OPD) for biopriming of unhealthy rice seeds was 9 or $12 \mathrm{~h}$.

For the pot experiments, due to the mean results derived from unhealthy rice seeds priming with different selected bacteria were not significantly different, we, therefore, pooled all data together and reported as one global mean (Figs. 6 and 7). At every cultivation phase of rice, the height of rice plants increased dramatically from seedling to flowering stages and stopped there (Fig. 6-a). There was no significant difference in the height of rice plants arising from any seeds. Also, the numbers of

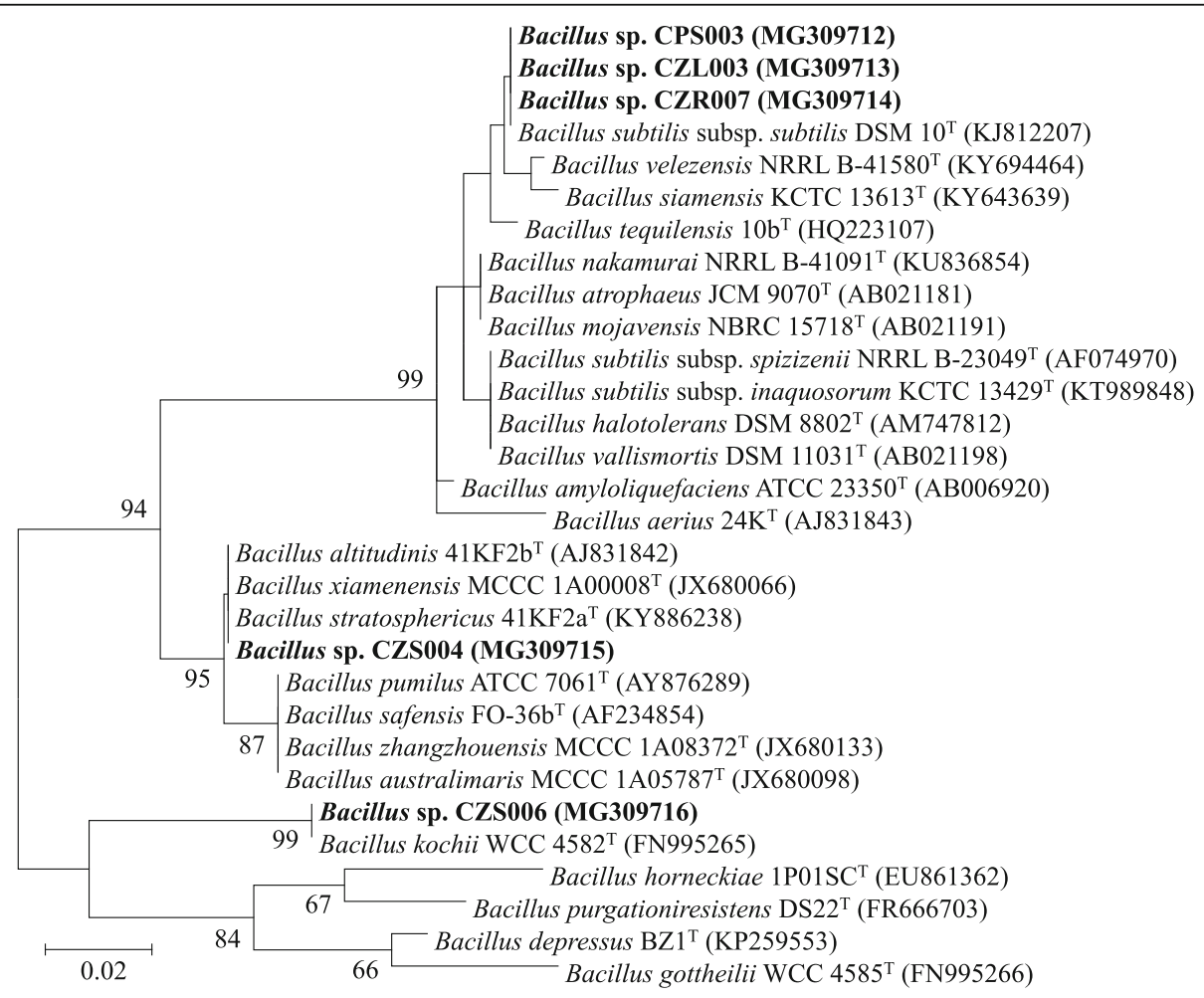

Fig. 3 Unrooted phylogenetic tree of 16S rRNA gene sequences of the best antifungal isolates of herbicide-tolerant endophytic bacteria of fieldgrowing rice. The isolated bacteria are in bold, and their GenBank accession numbers are in parentheses. The tree was constructed using the Maximum-Likelihood algorithm. Bootstrap values (based on 1000 replications) of $>60 \%$ are at the tree's nodes, and scale bar represents $2 \%$ dissimilarity 


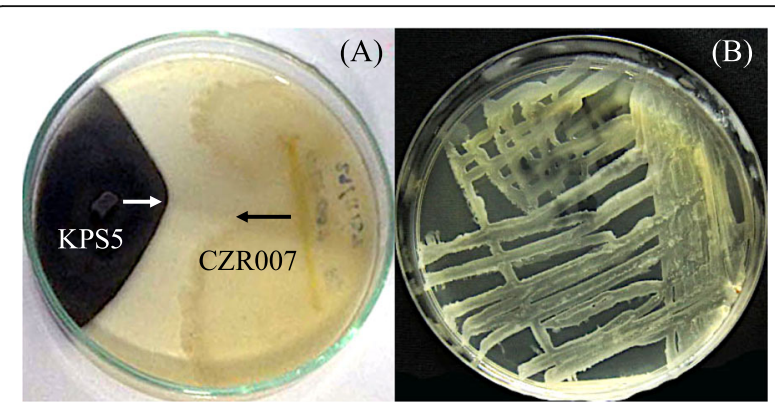

Fig. 4 Antifungal activity and herbicide tolerance of Bacillus sp. CZR007. The antifungal activity of isolate CZR007 was tested against the fungus, Bipolaris sp. KPS5 on potato dextrose agar (a). The herbicide tolerance of isolate CZRO07 was confirmed by checking viability of the bacterium on Luria-Bertani agar medium supplemented with $1.60 \mathrm{~mL}$ of a herbicide, Clomazone (b)

tillers and panicles per hill of rice plants originating from any seeds were not significantly different (Fig. 6-b and $-\mathrm{c}$ ). A similar trend of results was observed for the weight of 1000 healthy rice grains produced (Fig. 6-d). However, the percentages of healthy rice yields were not significantly different, when these yields were produced by rice plants emerging from non-treated or hydroprimed healthy seeds and chemical fungicide-treated or bioprimed unhealthy seeds (Figs. 6 and 7-e). Besides, such percentages were lowest for those rice yields produced by rice plants arising from non-treated or hydroprimed unhealthy seeds.

The antioxidant activity (referring to the \% Diphenyl1-Picrylhydrazyl (DPPH) radical inhibition) and total phenolic content as the health indicators of rice seedlings are present in Fig. 8. The antioxidant activities in roots of seedlings originating from 12-h hydroprimed healthy seeds and non-treated or any hydroprimed unhealthy seeds were significantly lower than the other conditions (Fig. 8-a). A similar trend of results was observed in the case of seedlings' shoots, but the antioxidant activity in shoots of seedlings emerging from 9-h hydroprimed healthy seeds decreased. The total phenolic contents in roots and shoots of seedlings were similar to the results of antioxidant activities (Fig. 8-b). The Enterobacterial repetitive intergenic consensus-polymerase chain reaction (ERIC-PCR) fingerprinting data to confirm in planta colonization of selected bacteria after seed biopriming are present in Fig. 9. At least a bacterial colony isolated from rice seedlings emerging from bioprimed unhealthy seeds exhibited $100 \%$ similarity of its fingerprinting data compared to those of selected bacteria used in seed biopriming.

\section{Discussion}

The paddy field is a huge playground of diverse microorganisms, and these tiny bugs play significant roles that provide either beneficial or adverse impacts on rice crop. When a plant disease occurs in the paddy field, they are easy to be dispersed and hard to be managed. DPD is a common disease of rice seeds that may arise in the productive stage of rice but more often during post-harvest storage. The causative agents of this disease are diverse fungi but are typically the members of the genera Alternaria, Bipolaris, Cercospora, Curvularia, Fusarium, and Sarocladium [2]. Based on our study, the fungus, Nigrospora was found for the first time as one among the potential pathogens of DPD. All pathogens damage rice seeds by initiating grain discoloration and consequently destroy the entire grain tissues.

Plant tissues of rice offer unique ecological niches for diverse microbes and some of which are potential PGP bacteria [15-17]. It was unsurprising that our isolated bacterial endophytes of rice, showing excellent antifungal activity against pathogenic fungi of DPD were all the members of the genus Bacillus. Many studies report that bacilli are ones among the best-known PGP bacteria of rice $[14,15,18,22]$. The PGP roles of bacilli in rice cultivation are diverse, which can act as a free-living diazotroph to supply nitrogen to rice, a producer of antimicrobial substances to suppress pest invasion, and a modifier of minerals in rice crop, etc. The different antifungal potentials of our bacilli can be a result of their phylotypic difference as well as the different fungal pathogens tested. It has been reported that variety of bacilli hold different lipopeptide genes which related to the antimicrobial activity, and such produced lipopeptide antibiotics can be those of the surfactin, iturin and fengycin families [23]. Moreover, all isolated bacilli can tolerate several herbicides, which could be an add-on feature to minimize the side effects of herbicide treatment on rice development in the commercial rice cultivation.

After biopriming of unhealthy rice seeds with the selected bacteria, priming duration for 9 or $12 \mathrm{~h}$ was optimal, supported by the lowest disease incidence and longer roots and shoots of rice seedlings germinated. The appropriate priming duration is a critical factor in seed priming technique, which affects the germination behavior and seedling vigor of various plant seeds, e.g., pinto bean [24] and bread wheat [25]. Xie et al. [26] found that soaking seeds of rice cultivar 9311 in Bacillus subtilis OKB105 for $2 \mathrm{~h}$ could increase the length of rice seedlings' shoots by $25.2 \%$. Another study performing rice seed biopriming with $B$. subtilis CIM and picomolar rutin could enhance also the growth and development of rice seedlings' roots and shoots [27]. We also found that hydropriming of unhealthy rice seeds could enhance rice development at the germination and seedling growth phases. This finding is concordant with a study unveiling that hydropriming of rice seeds could accelerate emergence and improve rice 


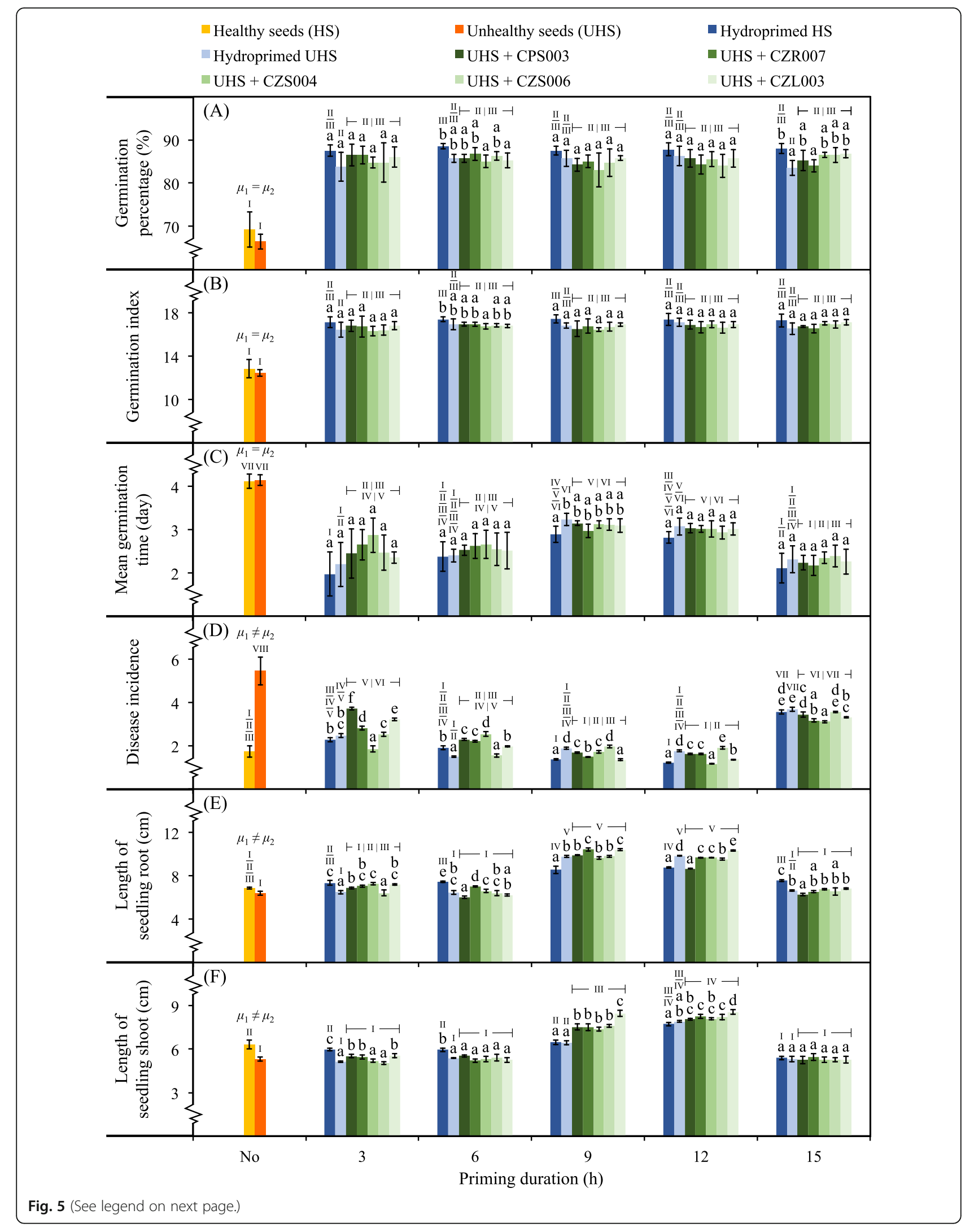




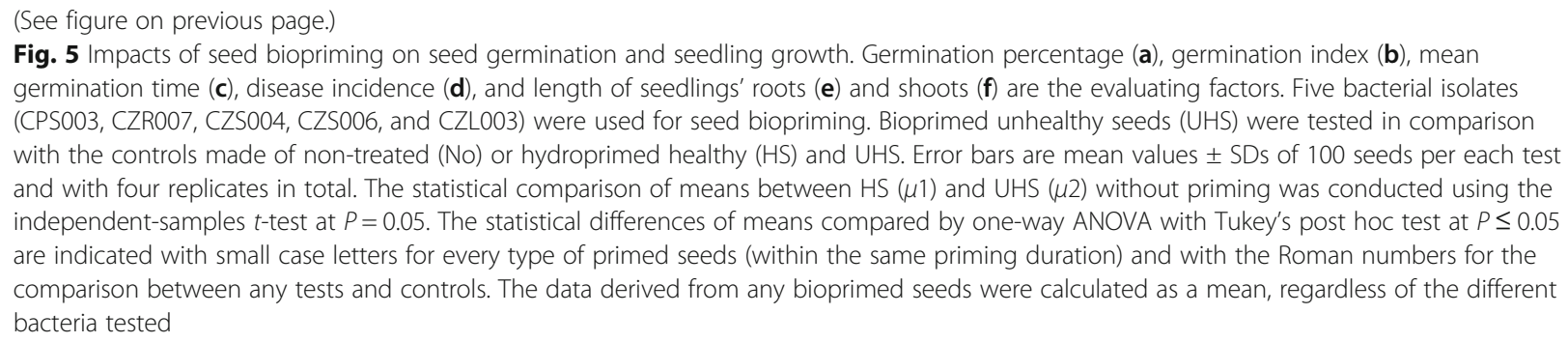

seedling vigor [28]. However, the results derived from the pot experiments suggested that biopriming of unhealthy rice seeds offered more significant support in the suppression of DPD than those hydropriming ones, evidenced by the better quality of rice yield produced. This finding would be an obvious result of PGP benefits provided by the bacteria used in seed biopriming.

Antioxidant and phenolic compounds are the keystone bioactive phytochemicals of rice, which indicate the nutritive quality of rice and play roles in plant-microbe interactions $[17,29]$. Our study revealed that most isolated bacilli used in biopriming of unhealthy rice seeds could statistically increase the two phytochemical contents in rice seedlings regardless of the different priming durations tested. This finding is an example mechanism of how such biopriming bacilli could immunize rice plants. Singh et al. [27] found that biopriming of rice seeds with $B$. subtilis CIM not only enhanced seedling growth but also induced the accumulations of photosynthetic pigments (i.e., chlorophyll and carotenoid) and phenolic and flavonoid contents in rice seedlings. Another study reported that antagonistic Bacillus spp. significantly enhanced the activities of antioxidative enzymes (e.g., peroxidase, polyphenol oxidase, phenylalanine ammonia-lyase) up to 4-fold, in leaves and roots of rice growing under hydroponic and soil conditions [30]. Besides, such antioxidative substances have been supposed to be elicitors of the induced systemic resistance in rice as their functions highly correlate with rice disease suppression [31, 32].

Effectively in planta colonization of beneficial microbes is a prime reason to prolong their bioactive functions in supporting growth and development of their host plants [13]. The mechanisms by which the endophytic bacteria enter the interiors of rice are similar to those by phytopathogenic bacteria, and some of entry paths like germinating radicles and root cracks assist the initiation of root colonization by bacteria [13]. It was found also that during germination of rice seeds bioprimed with $B$. subtilis OKB105, more than 150 genes of this bacterium exhibited significantly altered transcriptional levels [26]. For example, genes involved in metabolisms, nutrient transport and stress responses (e.g., $\operatorname{araA}, y w k A, y f l s, m t l A, y d g G$, etc.) were upregulated, while cheV, fliL, spmA and tua genes involved respectively in chemotaxis, motility, sporulation and teichuronic acid biosynthesis were downregulated [26]. The ERIC-PCR DNA fingerprinting technique carried out in our study proved that all isolated bacilli used in seed biopriming could extend their lives in the interiors of rice seedlings. Hence, the improved rice yields produced in the pot experiments by using seed stocks made of unhealthy rice seeds bioprimed with herbicide-tolerant endophytic bacteria would be a result of prolonged synergistic interactions between rice plants and the biopriming bacteria.

\section{Conclusions}

Biopriming of unhealthy rice seeds with herbicidetolerant endophytic bacteria of rice could suppress DPD of rice seeds. The synergistic interactions between biopriming bacteria and rice seeds optimized the growth and development of rice generated in subsequent cultivation, leading to the acceptable quality of rice yield produced. Therefore, seed biopriming would be a promising approach in the restoration of unhealthy rice seeds for use as rice seed stock, which underpins the use of green technology in sustainable agriculture of rice.

\section{Methods}

\section{Plant materials}

Any plant materials used in this study were identified by a curator, Tanawat Chaowasku and deposited publicly as herbariums for further references at the CMUB Herbarium, Department of Biology, Faculty of Science, Chiang Mai University, while their specimen voucher numbers initiated with CMUB are addressed elsewhere in this article.

Thai jasmine rice (O. sativa L. cv. KDML105) seeds (CMUB39907) stored without any treatment for 4-5 months after harvesting in a granary at Si Prachan District, Suphan Buri Province, Thailand. These seeds were commercially produced by a local farmer, and some of which were stored as seed stock for subsequent cultivation. The seeds were collected from the granary with the owner's permission and guidelines (no license needed), and they showed either apparent or no symptom of DPD. We classified the virulence degrees of DPD of these seeds into Grade A (healthy): no disease symptom, Grade B (unhealthy): 20-30\% visible symptom, and 


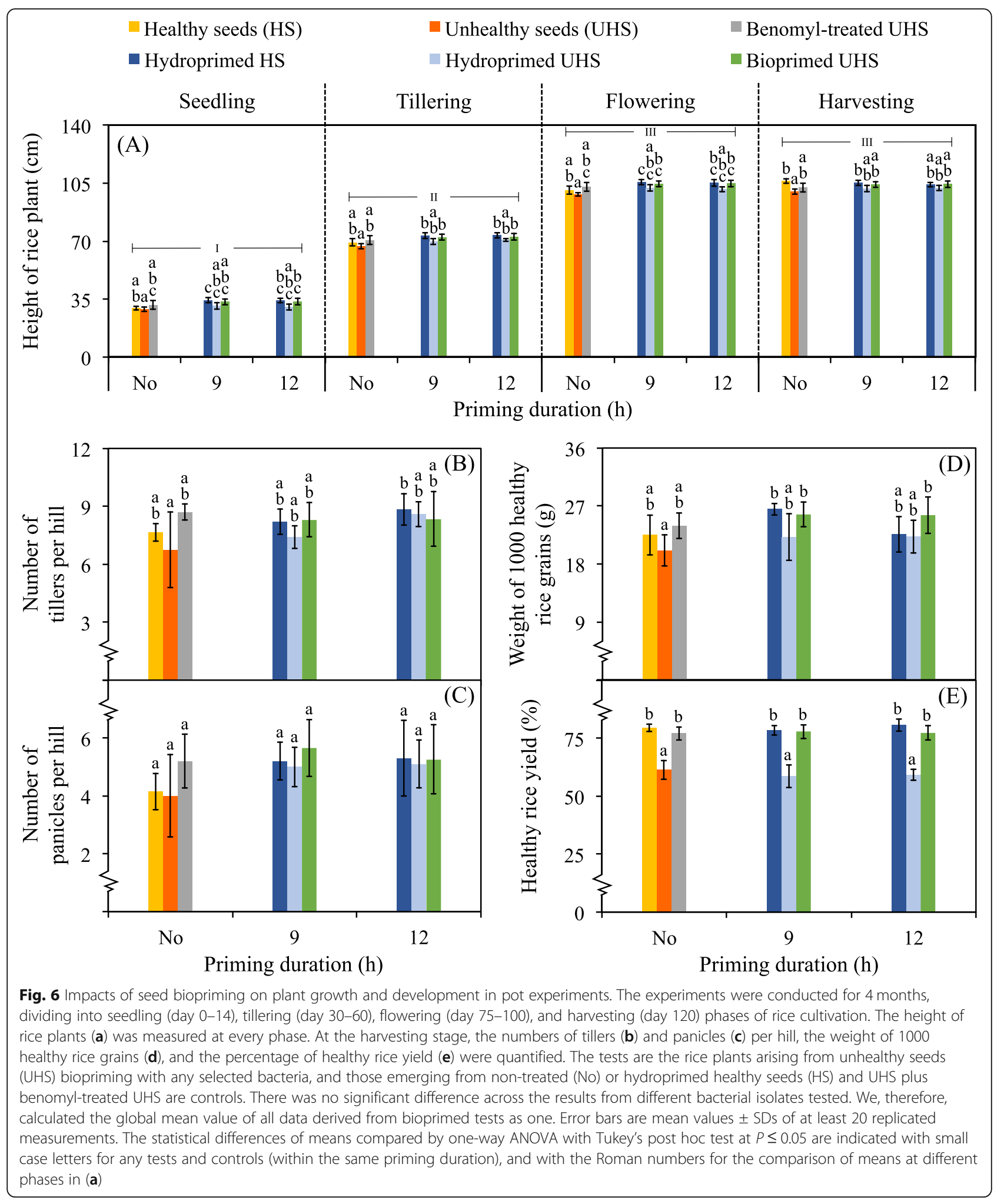

Grade C (diseased): $50-100 \%$ severe seed damage. The seeds were the sources for isolation of phytopathogenic fungi and used in biopriming experiments.
Two rice cultivars: Oryza sativa L. var. indica cv. Pathumthani 1 (CMUB39903 - CMUB39905) and Oryza sativa L. var. indica cv. RD41 (CMUB39906) were 


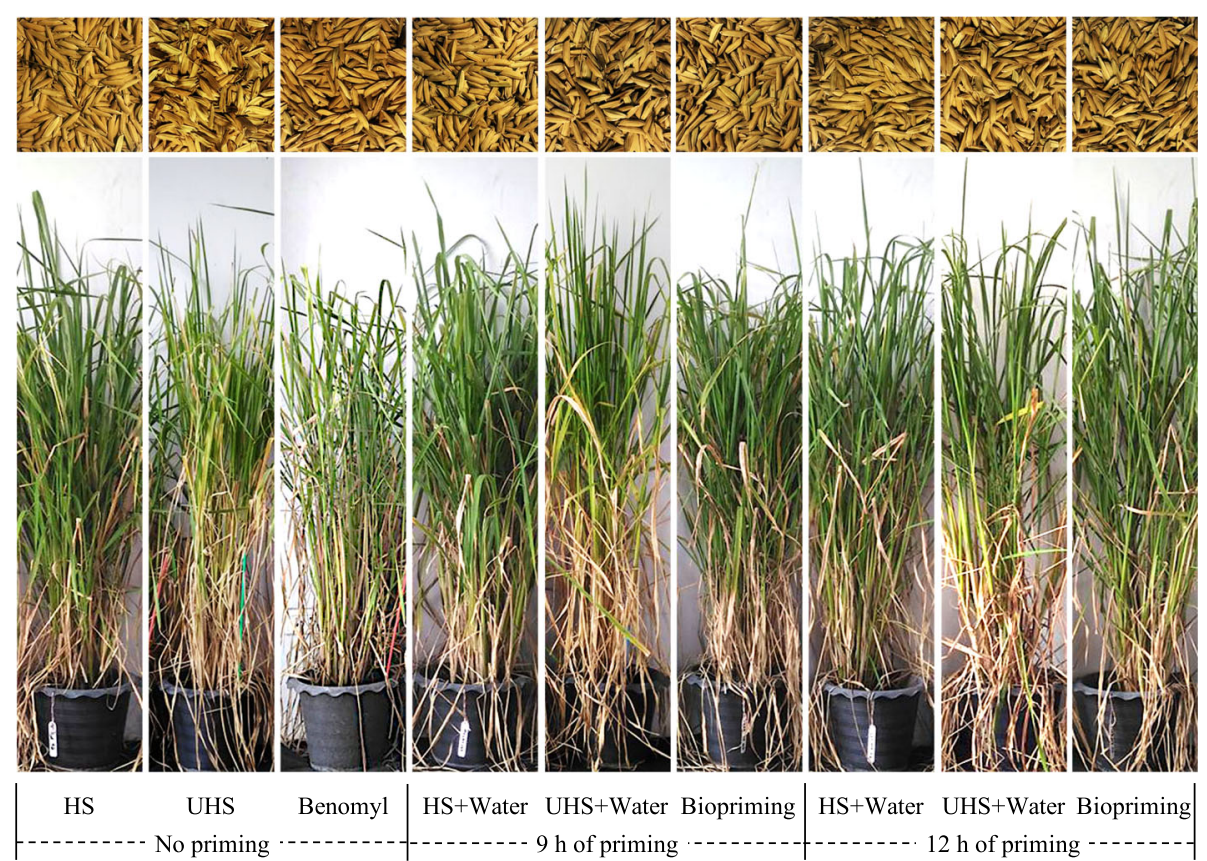

Fig. 7 Comparisons of rice plants and yields derived from different conditions tested in pot experiments. Rice plants and yields merging from healthy seeds (HS), unhealthy seeds (UHS), fungicide treated seeds, and primed seeds. The fungicide-treated seeds were prepared using UHS plus chemical fungicide, benomyl (Benomyl). The primed seeds were prepared using HS or UHS primed with water (HS + water or UHS + water) and UHS bioprimed with bacterial cell suspension made of Bacillus sp. CZRO07 (Biopriming). Seed hydropriming and biopriming were carried out for 9 and $12 \mathrm{~h}$. The pictures of rice plants and their yields were photographed at the harvesting stage in pot experiments

commercially cultivated by the local farmers at different field locations where different herbicides were applied to treat the fields (Table 2). These field-growing rice plants were collected by uprooting from the fields with the owners' permission and guidelines (no license needed). The farmers also kindly provided the information about the herbicide treatments and the ages of rice plants. The rice plants were packed in plastic bags and preserved in an icebox before transferring to the laboratory. After washing these rice plants several times under running tap water, they were divided as roots, stems, and leaves. Any plant materials had surfaces sterilized by soaking in a series of $70 \%(\mathrm{v} / \mathrm{v})$ ethyl alcohol for $1 \mathrm{~min}, 2 \%(\mathrm{v} / \mathrm{v})$ $\mathrm{NaOCl}$ for $2 \mathrm{~min}, 95 \%(\mathrm{v} / \mathrm{v})$ ethyl alcohol for $30 \mathrm{~s}$, and $30 \%(\mathrm{v} / \mathrm{v}) \mathrm{H}_{2} \mathrm{O}_{2}$ for $1 \mathrm{~min}$. The cleaned plant materials were washed four times with sterile distilled water to remove disinfectant residues and used as the sources for isolating herbicide-tolerant endophytic bacteria.

\section{Isolation of phytopathogenic fungi and their pathogenicity tests}

Diseased rice seeds (Grade C) served as the sources for isolation of fungal pathogens causing DPD. These seeds were washed several times under running tap water and their surfaces sterilized with $1 \%(\mathrm{w} / \mathrm{v}) \mathrm{NaOCl}$ for 10 min following by a final wash with sterile distilled water. Ten cleaned seeds were pasted on potato dextrose agar (PDA) medium
(Difco, USA) and incubated at $22^{\circ} \mathrm{C}$ for $5-8$ days. The appeared fungal colonies were subcultured on the new PDA medium until becoming axenic cultures and then preserved in $20 \%(\mathrm{v} / \mathrm{v})$ glycerol for storage and further studies.

Pathogenicity of isolated fungi was tested in vitro at germination and seedling growth phases of healthy rice seeds (Grade A), following Koch's postulates. Briefly, these seeds had their surfaces sterilized using the same protocol addressed before. For the germination test, five of the cleaned seeds were pasted on autoclaved planting paper and inoculated with $10 \mathrm{~mL}$ of sterile distilled water as the control or mycelial suspension made of each fungal isolate, then incubated at $30^{\circ} \mathrm{C}$. The mycelial suspension was prepared by scrapping 7-day-old fungal biomass growing on PDA medium at $30^{\circ} \mathrm{C}$. The biomass was ground in the presence of sterile distilled water, using aseptic mortar and pestle. The final concentration of such mycelial suspension was adjusted to $10^{4}$ propagules $\mathrm{mL}^{-1}$ by hemocytometer.

For the test at the seedling growth phase, the cleaned rice seeds were allowed to germinate on moist autoclaved planting papers at $30^{\circ} \mathrm{C}$ for 5 days. A seedling produced was aseptically transferred to grow further on Water agar medium in a test tube, where $1 \mathrm{~mL}$ of sterile distilled water (control) or each mycelial suspension was inoculated and incubated in a moist chamber at $25^{\circ} \mathrm{C}$. The pathogenicity level (i.e., weak, medium, and virulent) of each isolated fungus was assigned using the 


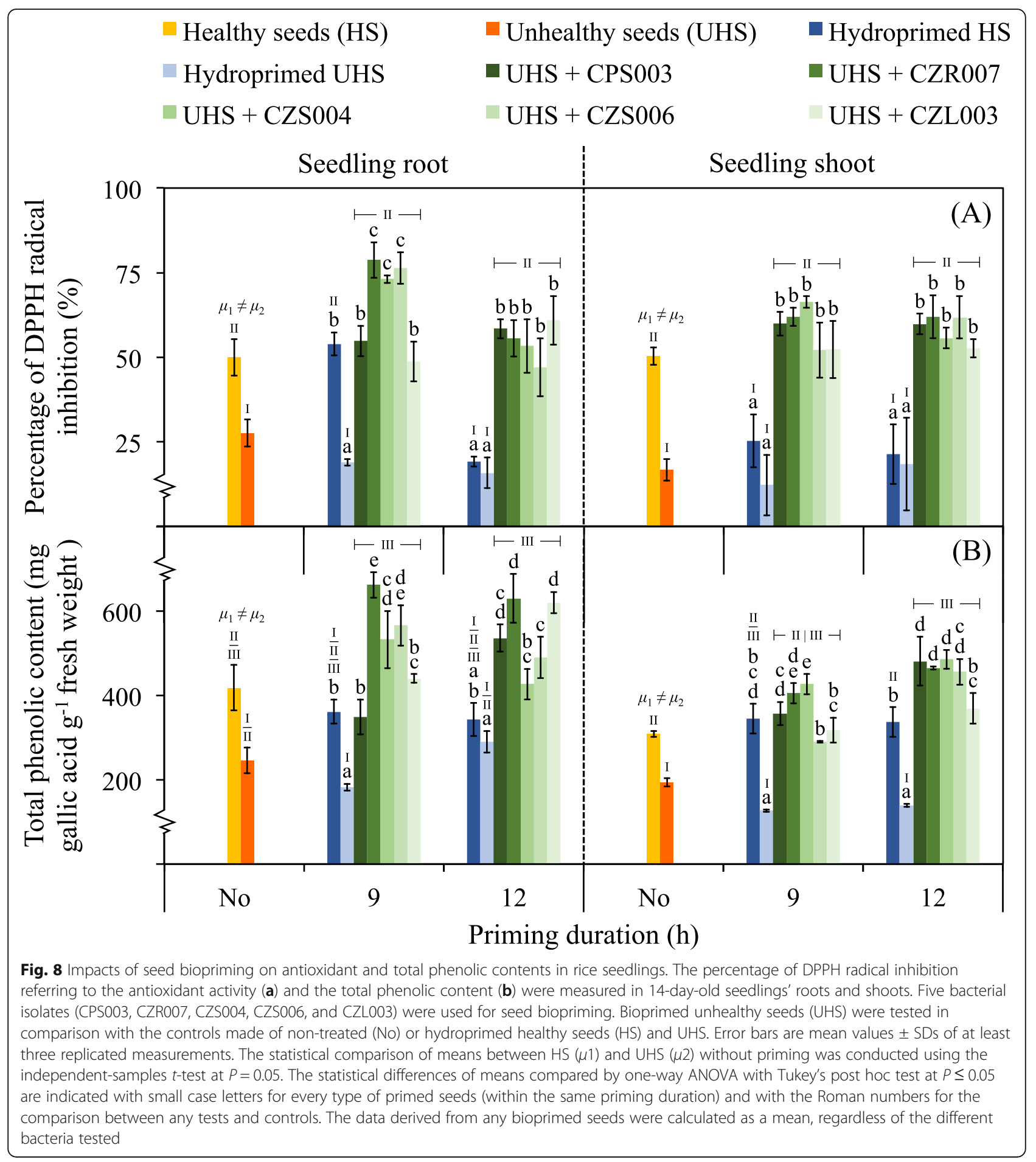

germination rate of seeds and seedling health observed every day.

\section{Isolation of herbicide-tolerant endophytic bacteria of rice and their antifungal potentials}

The prepared rice plant materials derived from the field cultivations were ground in the presence of sterile distilled water $(1 \mathrm{~mL})$, using aseptic mortar and pestle. The suspension $(100 \mu \mathrm{L})$ of ground plant materials was spread over Luria-Bertani (LB) agar medium (Himedia, India) supplemented with a set of herbicides applying in the field cultivation of rice (Table 2). Also, the washing liquid derived from the last step of the surface sterilization of each plant material described previously $(100 \mu \mathrm{L})$ was spread 


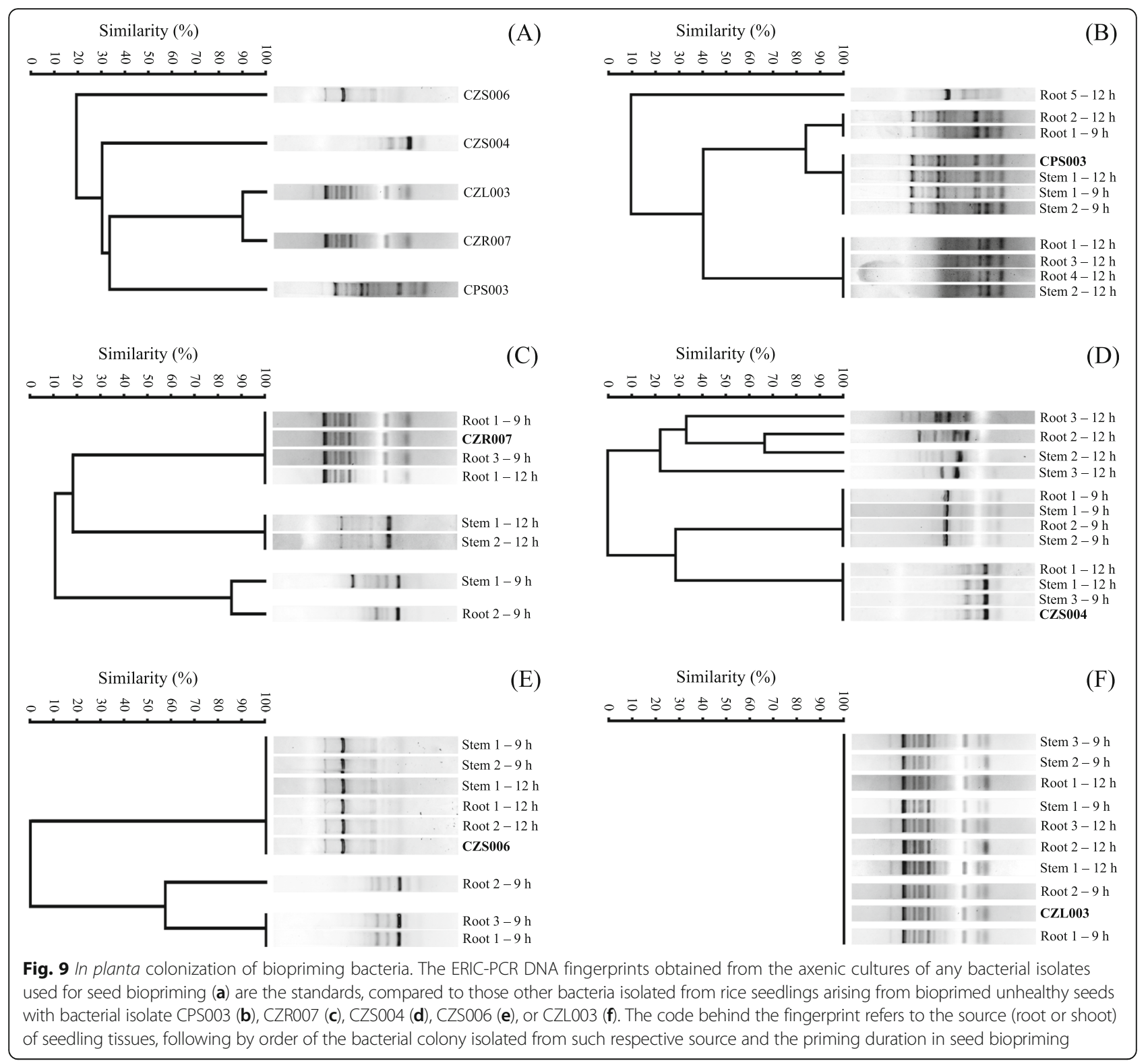

over the agar medium and served as a control to verify in planta origin of the bacteria isolated. Four seeded agar plates per each part of plant materials and controls were carried out and incubated at $30^{\circ} \mathrm{C}$ for 2 days. The visible bacterial colonies were subcultured onto the new agar medium until becoming axenic cultures, then preserved in $20 \%(\mathrm{v} / \mathrm{v})$ glycerol for storage and further studies.

Antifungal activity of each isolated bacterium against a set of fungal isolates showing virulent pathogenicity of DPD was assayed using dual culture method on PDA medium. Briefly, a bacterial colony (2-day-old culture growing previously on LB agar medium at $\left.30^{\circ} \mathrm{C}\right)$ was streaked $(5-\mathrm{cm}$ in length) on PDA medium at 2-cm away from the edge of the plate. At the opposite of the bacterial streak, the fungal mycelium as a disc of $5.5 \mathrm{~mm}$ diameter (5-day-old culture growing previously on PDA medium at $30^{\circ} \mathrm{C}$ ) was inoculated at 2-cm away from the edge of the plate. All assayed plates were incubated at $30^{\circ} \mathrm{C}$, in which the radius growth of fungal colony was measured every day. Fungal growth in the absence of test bacterium served as the control. The percentage of inhibition was calculated using equation (i), where $d_{\text {control }}$ is an average size ( $\varnothing$ in $\mathrm{mm}$ ) of the fungal colony in the control and $d_{\text {assay }}$ is that in the dual culture assay. \% Inhibition $=\frac{d_{\text {control }}-d_{\text {asay }}}{d_{\text {control }}} \times 100$ (i).

\section{Identification and classification of isolated microbes}

The isolated fungi showing virulent pathogenicity of DPD were identified at the generic level, using their internal transcribed spacer (ITS) gene sequence data. Each 
fungus was grown on PDA medium at $30{ }^{\circ} \mathrm{C}$ for 7 days, in which the fungal biomass was scraped out and suspended in sterile distilled water. The biomass collected by centrifugation at $12100 \mathrm{~g}$ for $5 \mathrm{~min}$ was used for DNA extraction with Plant Genomic DNA Mini Kit (Geneaid Biotech Ltd., Taiwan), following the manufacturer's instruction. Extracted DNA was the template for amplifying the fungal ITS1-5.8S rDNA - ITS2-26S rDNA region by PCR, using Taq DNA Polymerase and Standard Taq Buffer from New England BioLabs, USA. PCR $(25 \mu \mathrm{L})$ contained $2.5 \mu \mathrm{L}$ of $10 \times$ Standard Taq Reaction Buffer, $0.5 \mu \mathrm{L}$ of $10 \mathrm{mM}$ dNTPs, $0.125 \mu \mathrm{L}$ of Taq DNA Polymerase, $0.5 \mu \mathrm{L}$ of each $10 \mu \mathrm{M}$ primer (ITS1: 5' TTTCCGTAGGTGAACCTGC $3^{\prime}$ and ITS4: 5' TCCTCCGCTTATTGATATGC 3' [33]), $0.1 \mu \mathrm{L}$ of template DNA, and the volume was adjusted with nucleasefree water. PCR was carried out using a thermocycler with the following condition: $5 \mathrm{~min}$ initial denaturation at $94{ }^{\circ} \mathrm{C}, 30$ cycles of $1.5 \mathrm{~min}$ denaturation at $94{ }^{\circ} \mathrm{C}, 2$ min annealing at $52^{\circ} \mathrm{C}$ and $1 \mathrm{~min}$ extension at $72{ }^{\circ} \mathrm{C}$, and 5 min final extension at $72^{\circ} \mathrm{C}$.

The isolated bacteria showing excellent antifungal activity were identified at the generic level, using their $16 \mathrm{~S}$ rRNA gene sequence data. Each bacterium was grown in $50 \mathrm{~mL}$ of LB broth with shaking incubation at $250 \mathrm{rpm}$, $30^{\circ} \mathrm{C}$ for 2 days. The bacterial biomass was collected by centrifugation at $12000 \mathrm{~g}$ for $5 \mathrm{~min}$ and used as the template DNA for amplifying the 16S rRNA gene sequence. Following the same PCR compositions mentioned above, except for the primers that were fD1 5' AGAGTTTGAT CCTGGCTCAG $3^{\prime}$ and rP2 5' ACGGCTACCTTGTT ACGACTT 3' [34]. PCR was carried out using a thermocycler with the following condition: $5 \mathrm{~min}$ predenaturation at $95^{\circ} \mathrm{C}, 30$ cycles of 1 min denaturation at $94^{\circ} \mathrm{C}, 1 \mathrm{~min}$ annealing at $55^{\circ} \mathrm{C}$ and $1.5 \mathrm{~min}$ extension at $72^{\circ} \mathrm{C}$, and $10 \mathrm{~min}$ final extension at $72^{\circ} \mathrm{C}$.

Any PCR products were sequenced to retrieve their nucleotide sequence data with a service provided by 1 st BASE, Singapore. The gene sequences obtained were checked using BioEdit (www.mbio.ncsu.edu/BioEdit/ bioedit.html) and identified by comparison with the public nucleotide databases available in GenBank (https:// blast.ncbi.nlm.nih.gov/Blast.cgi) plus MycoBank (http:// www.mycobank.org) for the fungal ITS sequences or together with EZBioCloud (www.ezbiocloud.net) for the bacterial 16S rRNA gene sequences. The highly related nucleotide sequences were collected, aligned with MUSCLE, and used for constructing phylogenetic trees in MEGA7 (www.megasoftware.net).

\section{Seed biopriming}

The method for biopriming of rice seeds was carried out using modified protocols described by Singh et al. [27] and Sivakumar et al. [35]. Briefly, unhealthy rice seeds
(Grade B) were used for biopriming by soaking them in aqueous suspensions of the isolated bacteria showing excellent antifungal activity. Each bacterium was previously grown in LB broth at $30^{\circ} \mathrm{C}$ with shaking at $250 \mathrm{rpm}$ for 2 days, and its biomass was collected by centrifugation at $9660 \mathrm{~g}$ for $5 \mathrm{~min}$. The bacterial biomass was washed twice, re-suspended and adjusted its optical density (absorbance) at the wavelength of $600 \mathrm{~nm}$ using sterile distilled water to 0.2 that corresponded to $10^{8}$ colonies forming unit per $\mathrm{mL}$. The seeds were soaked in each bacterial suspension for $3,6,9,12$, and $15 \mathrm{~h}$, aiming to find the OPD in biopriming. All soaked seeds were air dried at $25^{\circ} \mathrm{C}$ till their moisture contents were the same as before priming $(\sim 12 \%)$ monitored by a rice moisture meter, RICETER F-514 (Kett Electric Laboratory, Japan) to avoid the impacts of seed moisture change caused by different priming durations. In parallel, a set of controls was constructed to assess the capacity of seed biopriming, i.e., non-treated or hydroprimed healthy and unhealthy seeds. For seed hydropriming, it was carried out in the same way as for biopriming but used solely sterile distilled water (no bacterial cells). Besides, unhealthy seeds mixed with 1.3\% (w/w) Benomyl (Sims Agrow Cheme, Thailand) served as a chemical fungicide-treated control in pot experiments. Any rice seeds with and without treatment were kept at $4{ }^{\circ} \mathrm{C}$ for 6 months before use in further assessments.

\section{Post-biopriming assessments in the full life cycle of the rice crop}

The impacts of seed biopriming on fertility recovery and disease suppression of unhealthy rice seeds, since seed germination until harvesting of rice yield were evaluated. GP, GI, MGT, DI, and lengths of seedlings' roots and shoots, were evaluating factors at the germination and seedling growth phases and also used as the criteria for assigning OPD in biopriming. These parameters were quantified after allowing seeds to germinate by a standard between-paper germination test described in the International Seed Testing Association's handbook [36]. Non-treated, hydroprimed or bioprimed healthy and unhealthy rice seeds previously prepared were used in these measurements, which were carried out in four replications (100 seeds per each) and incubated at $25^{\circ} \mathrm{C}$ in plastic bags to prevent humidity loss.

The germinated seeds counting for the first time on the third day of incubation and the seventh day for the last count were recorded and subjected to the calculation of GP [36]. GI was calculated using the equation (ii) described in the Association of Official Seed Analysts' handbook [37], in which $G_{x}$ is the number of germinated seeds counting at day $x$. 


$$
\mathrm{GI}=\frac{G_{1}}{1}+\frac{G_{2}}{2}+\ldots+\frac{G_{x}}{\mathrm{x}}
$$

The equation (iii) described by Ellis and Roberts [38] was used to calculate MGT, where $n$ is the number of seeds germinating on day $d$ and $d$ is the number of days counting from the beginning of germination.

$$
\mathrm{MGT}=\frac{\sum d \cdot n}{\sum n}
$$

At the seventh day after allowing rice seeds to germinate, DI scores were determined using the grain discoloration criteria of Mew and Misra [39] as no incidence $=0$, $<1 \%=1,1-5 \%=3,6-25 \%=5,26-50 \%=7$, and $51-$ $100 \%=9$. Based on this scoring, DI was computed using the equation (iv), where each $N_{3}, N_{5}, N_{7}$, and $N_{9}$ is respectively the number of seedlings with score $3,5,7$, and 9 , and $N_{t}$ is the total number of scored seedlings.

$$
\mathrm{DI}=\frac{N_{3}+N_{5}+N_{7}+N_{9}}{N_{t}}
$$

Lengths of seedlings' roots and shoots were measured using 14-day-old rice seedlings emerging from any treated and control seeds.

The pot experiments were constructed to assess how seed biopriming benefits rice cultivation and quality of rice yield produced. The tests were conducted with a randomized complete block design with five replications (4 pots per each) under the controllable greenhouse conditions. Each container $(\varnothing=8$ in, height $=25 \mathrm{~cm})$ was filled with $2 \mathrm{~kg}$ of agricultural soil homogenized with coir and cow manure at a ratio of $4 / 1 / 1(\mathrm{w} / \mathrm{w} / \mathrm{w})$. The soil type was clayey loam identified by the hydrometer method [40]. The 14-day-old rice seedlings emerging from either non-treated or treated seeds were prepared in the same way as addressed previously. At least three seedlings were planted at the center of each pot and allowed to grow for 5 days when only the best-grown seedling was remained. With the aim to imitate the field conditions for commercial rice cultivation, every pot was fertilized twice with $30 \mathrm{~g}$ of Nitrogen-PhosphorusPotassium (N46-P0-K0) fertilizer for the first time (20 days after planting) and $60 \mathrm{~g}$ of N16-P16-K16 for the last time (45 days after planting). The field concentration of each fertilizer denoted by farmers was 30 and $60 \mathrm{~kg} \mathrm{ha}^{-1}$ for N46-P0-K0 and N16-P16-K16, respectively. A set of herbicides was also applied twice by spraying on soil surrounding rice plants when they were 10 and 25 days old. The herbicides used were $0.64 \mathrm{~mL} \mathrm{~L}^{-1}$ Clomazone plus $1.44 \mathrm{~mL} \mathrm{~L}^{-1}$ Propanil for the first time and $0.276 \mathrm{~mL} \mathrm{~L}^{-1}$ Fenoexprop-P-Ethyl for the second time. The growth phases of rice after planting comprised of seedling (day $0-14$ ), tillering (day 30-60), flowering (day 75-100), and harvesting (day 120). Growth and health indexes of rice, including the height of rice plants at every growth phase and the numbers of tillers and panicles per hill, the weight of 1000 healthy rice grains and the percentage of healthy rice yield at the harvesting stage were measured and used to determine the benefits of seed biopriming.

\section{Analyses of seedling phytochemicals}

As well-being indicators, two phytochemicals, i.e., antioxidants and total phenolic contents in rice seedlings' roots and shoots were quantified using modified colorimetric methods described by Sadh et al. [41]. Nontreated, hydroprimed or bioprimed healthy and unhealthy rice seeds previously prepared were used to produce 14-day-old seedlings. A modified DPPH radical scavenging assay was used to measure antioxidant activity. Briefly, $500 \mathrm{mg}$ of seedlings' shoots or roots was extracted using $2 \mathrm{~mL}$ of $95 \%(\mathrm{v} / \mathrm{v})$ ethanol, and the mixture was precipitated by cold centrifugation $\left(4^{\circ} \mathrm{C}\right)$ at $9660 \mathrm{~g}$ for $20 \mathrm{~min}$. The derived supernatant or the extracting solvent as a control $(0.5 \mathrm{~mL})$ was mixed with $3 \mathrm{~mL}$ of 60 $\mathrm{M} \mathrm{DPPH}$ by vortexing and incubated in the dark at $25^{\circ} \mathrm{C}$ for $30 \mathrm{~min}$. The absorbance at $517 \mathrm{~nm}\left(\mathrm{~A}_{517}\right)$ of the produced mixture was measured by a spectrophotometer, while the antioxidant activity was determined with the percentage of DPPH radical inhibition, using the modified equation (v).

$$
\% \text { DPPH radical inhibition }=\frac{A_{517 \text { control }}-A_{517 \text { extract }}}{A_{517 \text { control }}} \times 100
$$

For the quantification of the total phenolic contents, $50 \mathrm{mg}$ of seedlings' shoots or roots was extracted by mixing with $2.5 \mathrm{~mL}$ of $95 \%(\mathrm{v} / \mathrm{v})$ ethanol and incubated at $0{ }^{\circ} \mathrm{C}$ for $48-72 \mathrm{~h}$. The extract was combined using a homogenizer and precipitated by cold centrifugation $\left(4^{\circ} \mathrm{C}\right)$ at $9660 \mathrm{~g}$ for $10 \mathrm{~min}$. The derived supernatant or the extracting solvent as a control $(1 \mathrm{~mL})$ was mixed with $2.5 \mathrm{~mL}$ of $95 \%(\mathrm{v} / \mathrm{v})$ ethanol, $5 \mathrm{~mL}$ of sterile distilled water, and $0.5 \mathrm{~mL}$ of $50 \%(\mathrm{v} / \mathrm{v})$ Folin-Ciocalteu reagent, by vortexing and left at $25^{\circ} \mathrm{C}$ for $5 \mathrm{~min}$. The mixture was added with $1 \mathrm{~mL}$ of $5 \%(\mathrm{v} / \mathrm{v}) \mathrm{Na}_{2} \mathrm{CO}_{3}$ and incubated in the dark at $25^{\circ} \mathrm{C}$ for $1 \mathrm{~h}$. The absorbance at $725 \mathrm{~nm}$ of the produced mixture was measured by a spectrophotometer, while the total phenolic content in mg gallic acid per $\mathrm{g}$ fresh weight of plant materials was calculated by corresponding the absorbance values to the standard curve of the known gallic acid concentrations.

\section{Confirmation of in planta colonization by herbicide- tolerant endophytic bacteria}

The capability of PGP bacteria to colonize the interiors of rice is a promising feature that these bacteria can benefit the entire life cycle of rice growth and 
development. ERIC-PCR [42] was carried out to confirm the in planta colonization of the bacteria selected for seed biopriming. Briefly, surface-sterilized roots and shoots of 14-day-old rice seedlings emerging from bioprimed seeds were prepared as described previously. The cleaned plant materials $(1 \mathrm{~g})$ were ground in the presence of sterile distilled water $(9 \mathrm{~mL})$, using aseptic mortar and pestle. The ground plant suspension $(1 \mathrm{~mL})$ was diluted 10 -fold serially, and $100 \mu \mathrm{L}$ of some dilutions $\left(10^{3}-10^{5}\right)$ was spread over LB agar medium supplemented with a set of herbicides used for the bacterial isolation. The experiments were carried out in triplicate, and the growing bacterial colonies were collected randomly and used as a template DNA for ERIC-PCR, while axenic cultures of the bacteria selected for seed biopriming served as the controls. A pair of primers [43], including ERICIR (5' -ATGTAAGCTCCTGGGGATTCAC-3') and ERIC2 (5'-AAGTAAGTGACTGGGGTGAGCG-3') was used in ERIC-PCR, in which the other PCR compositions were the same as mentioned before. ERIC-PCR was performed using a thermocycler with the following condition: 5 min pre-denaturation at $95^{\circ} \mathrm{C}, 30$ cycles of $1 \mathrm{~min}$ denaturation at $94{ }^{\circ} \mathrm{C}, 1 \mathrm{~min}$ annealing at $52^{\circ} \mathrm{C}$ and $1 \mathrm{~min}$ extension at $72^{\circ} \mathrm{C}$, and $10 \mathrm{~min}$ final extension at $72{ }^{\circ} \mathrm{C}$. The PCR product $(10 \mu \mathrm{L})$ was analyzed using $1.5 \%(\mathrm{w} / \mathrm{v})$ agarose gel electrophoresis at $100 \mathrm{~V}$ for $3 \mathrm{~h}$. The DNA fingerprint on the gel was viewed and imaged by a Gel Doc ${ }^{\mathrm{Tm}} \mathrm{XR}+$ Gel Documentation System (Biorad, USA), after staining with $0.5 \mathrm{~g} \mathrm{~mL}^{-1}$ ethidium bromide. The fingerprints derived from different bacterial colonies and controls were clustered and analyzed for their similarity percentage by using PAST version 3.20 (https:// folk.uio.no/ohammer/past/) [44].

\section{Statistical analysis}

Comparisons of mean values and standard deviations (SDs) obtained from any measurements were performed using the independent-samples $t$-test or analysis of variance (ANOVA) with Tukey's post hoc tests, all available in the SPSS version 25.0 (SPSS, Chicago IL, USA) software package. The statistical results and significance $(P)$ levels $(P \leq 0.05)$ are addressed elsewhere in this article.

\footnotetext{
Abbreviations

ANOVA: Analysis of variance; DI: Disease incidence; DNA: Deoxyribonucleic acid; DPD: Dirty panicle disease; DPPH: Diphenyl-1-Picrylhydrazyl; ERICPCR: Enterobacterial repetitive intergenic consensus-PCR; Gl: Germination index; GP: Germination percentage; ITS: Internal transcribed spacer; LB: LuriaBertani; MGT: Mean germination time; OPD: Optimal priming duration; PCR: Polymerase chain reaction; PDA: Potato dextrose agar; PGP: Plant growth-promoting
}

\section{Acknowledgements}

We gratefully acknowledge Mr. Pairot Kaewmak (a farmer in Suphan Buri Province) for his kindness in providing us the permission to use his rice seeds in this study. The authors also thank the other local farmers who allowed us to collect field-growing rice seedlings as for the sources of isolating endophytic bacteria and sincerely provided us the information about herbicides used in their rice cultivation.

\section{Authors' contributions}

CR planed and performed the experiments and prepared the manuscript. SL and WTS gave advices regarding the work and interpretation of results. RS supervised the work, wrote and edited the manuscript. All authors have read and approved the manuscript.

\section{Funding}

CR is supported by Phranakhon Rajabhat University. CR and SL have financial support from Thailand Research Fund (TRF Grant: RTA5880006). WTS and RS have funding support from the Engineering and Physical Sciences Research Council of the UK (EPSRC Grant: EP/K038885/1). The funders did not play roles in the design and execution of this research, in the analysis and interpretation of data, and in writing the manuscript.

\section{Availability of data and materials}

All data generated during this study are included in this published article. The nucleotide sequences derived from the isolated microbes in this study are publicly available at GenBank (https://www.ncbi.nlm.nih.gov/genbank/) with accession numbers; MG309751-MG309756 for fungal isolates (Table 1 and Fig. 1) and MG309712-MG309716 for bacterial isolates (Table 3 and Fig. 3).

Ethics approval and consent to participate

Not applicable.

\section{Consent for publication}

Not applicable.

\section{Competing interests}

The authors declare that they have no competing interest.

\section{Author details}

${ }^{1}$ Department of Agricultural Management Technology, Faculty of Science and Technology, Phranakhon Rajabhat University, Bangkok 10220, Thailand. ${ }^{2}$ Microbiology Division, Department of Biology, Faculty of Science, Chiang Mai University, Chiang Mai 50200, Thailand. ${ }^{3}$ Center of Excellence in Microbial Diversity and Sustainable Utilization, Chiang Mai University, Chiang Mai 50200, Thailand. ${ }^{4}$ Academy of Science, The Royal Society of Thailand, Bangkok 10300, Thailand. ${ }^{5}$ Infrastructure and Environment Research Division, School of Engineering, University of Glasgow, Glasgow G12 8LT, UK.

Received: 16 May 2019 Accepted: 17 December 2019

Published online: 23 December 2019

\section{References}

1. Thailand Office of Agricultural Economics. http://www.oae.go.th/view/1/ Information/ EN-US (2018). Accessed 1 Sep 2018.

2. Charoenrak P, Chamswarng C. Efficacies of wettable pellet and fresh culture of Trichoderma asperellum biocontrol products in growth promoting and reducing dirty panicles of rice. Agric Nat Resour. 2016;50:243-9.

3. Butt AR, Yaseen SI, Javaid A. Seed-borne mycoflora of stored rice grains and its chemical control. J Anim Plant Sci. 2011;21:193-6.

4. Ghosh T, Biswas MK, Guin C, Roy P, Aikat K. A review on seed borne mycoflora associated with different cereal crop seeds and their mamagement. Plant Cell Biotechnol Mol Biol. 2018;19:107-17.

5. Murdoch $L$ Thailand's failed rice scheme creates moulding mountains of grain. 2013 https://www.smh.com.au/world/thailands-failed-rice-schemecreates-moulding\%2D\%2D-mountains-of-grain-20130724-2qjdy.html. Accessed 1 Sep 2018.

6. Naveenkumar R, Muthukumar A, Sangeetha G, Mohanapriya R. Developing eco-friendly biofungicide for the management of major seed borne diseases of rice and assessing their physical stability and storage life. C R Biol. 2017;340:214-25.

7. Tang T, Liu X, Wang P, Fu W, Ma M. Thiamethoxam seed treatment for control of rice thrips (Chloethrips oryzae) and its effects on the growth and yield of rice (Oryza sativa). Crop Prot. 2017;98:136-42.

8. Pareja L, Fernandez-Alba AR, Cesio V, Heinzen H. Analytical methods for pesticide residues in rice. Trends Analyt Chem. 2011;30:270-91. 
9. Carvalho FP. Agriculture, pesticides, food security and food safety. Environ Sci Pol. 2006;9:685-92.

10. Rekha SN, Naik R, Prasad R. Pesticide residue in organic and conventional food-risk analysis. J Chem Health Saf. 2006;13:12-9.

11. Begum MM, Sariah M, Puteh AB, Zainal Abidin MA, Rahman MA, Siddiqui Y. Field performance of bio-primed seeds to suppress Colletotrichum truncatum causing damping-off and seedling stand of soybean. Biol Control. 2010;53:18-23.

12. Paparella S, Araújo SS, Rossi G, Wijayasinghe M, Carbonera D, Balestrazzi A. Seed priming: state of the art and new perspectives. Plant Cell Rep. 2015;34: 1281-93.

13. Mahmood A, Turgay OC, Faroog M, Hayat R. Seed biopriming with plant growth promoting rhizobacteria: a review. FEMS Microbiol Ecol. 2016;92:1-14.

14. Wright B, Rowse HR, Whipps JM. Application of beneficial microorganisms to seeds during drum priming. Biocontrol Sci Tech. 2003;13:599-614.

15. Mano $H$, Morisaki $H$. Endophytic bacteria in the rice plant. Microbes Environ. 2008;23:109-17.

16. Rangjaroen C, Sungthong R, Rerkasem B, Teaumroong N, Noisangiam R, Lumyong S. Untapped endophytic colonization and plant growthpromoting potential of the genus Novosphingobium to optimize rice cultivation. Microbes Environ. 2017:32:84-7.

17. Nakaew N, Sungthong R. Seed phytochemicals shape the community structures of cultivable actinobacteria-inhabiting plant interiors of Thai pigmented rice. Microbiologyopen. 2018;7:e591.

18. Ji SH, Gururani MA, Chun S-C. Isolation and characterization of plant growth promoting endophytic diazotrophic bacteria from Korean rice cultivars. Microbiol Res. 2014;169:83-98.

19. Benyamin L, Buyung H, Siti H, Erna S, Laily IW, Kartika K, Lindi L, Yunin Y, Mei M. Recognizing farmers' practices and constraints for intensifying rice production at riparian wetlands in Indonesia. NJAS-Wagen J Life Sci. 2018; 85:10-20.

20. Hosoya K, Sugiyama S-I. Weed communities and their negative impact on rice yield in no-input paddy fields in the northern part of Japan. Biol Agric Hortic. 2017;33:215-24.

21. Wisler G, Norris RF. Interactions between weeds and cultivated plants as related to management of plant pathogens. Weed Sci. 2009;53:914-7.

22. Kakar KU, Nawaz Z, Cui Z, Almoneafy AA, Ullah R, Shu QY. Rhizosphereassociated Alcaligenes and Bacillus strains that induce resistance against blast and sheath blight diseases, enhance plant growth and improve mineral content in rice. J Appl Microbiol. 2017;124:779-96.

23. Saechow S, Thammasittirong A, Kittakoop P, Prachya S, Thammasittirong SNR. Antagonistic activity against dirty panicle rice fungal pathogens and plant growth-promoting activity of Bacillus amyloliquefaciens BAS23. J Microbiol Biotechnol. 2018;28:1527-35.

24. Ghassemi-Golezani K, Chadardooz-Jeddi A, Nasrollahzadeh S, Moghaddam M. Effects of hydro-priming duration on seedling vigour and grain yield of pinto bean (Phaseolus vulgaris L.) cultivars. Not Bot Hort Agrobot Cluj. 2010; 38:109-13.

25. Yari L, Aghaalikani M, Khazaei F. Effect of seed priming duration and temperature on seed germination behavior of bread wheat (Triticum aestivum L.). ARPN J Agric Biol Sci. 2010;5:1-6.

26. Xie $S$, Wu H, Chen L, Zang H, Xie Y, Gao X. Transcriptome profiling of Bacillus subtilis OKB105 in response to rice seedlings. BMC Microbiol. 2015;15:1-14.

27. Singh A, Gupta R, Pandey R. Rice seed priming with picomolar rutin enhances rhizospheric Bacillus subtilis CIM colonization and plant growth. PLoS One. 2016;11:e0146013.

28. Matsushima K-I, Sakagami J-I. Effects of seed hydropriming on germination and seedling vigor during emergence of rice under different soil moisture conditions. Am J Plant Sci. 2013;4:1584-93.

29. Goufo P, Trindade H. Rice antioxidants: phenolic acids, flavonoids, anthocyanins, proanthocyanidins, tocopherols, tocotrienols, $\gamma$-oryzanol, and phytic acid. Food Sci Nutr. 2014;2:75-104.

30. Rais A, Jabeen Z, Shair F, Hafeez FY, Hassan MN. Bacillus spp., a bio-control agent enhances the activity of antioxidant defense enzymes in rice against Pyricularia oryzae. PLoS One. 2017;12:1-17.

31. Filippi MCC, Da Silva GB, Silva-Lobo VL, Côrtes MVC, Moraes AJG, Prabhu AS Leaf blast (Magnaporthe oryzae) suppression and growth promotion by rhizobacteria on aerobic rice in Brazil. Biol Control. 2011;58:160-6.

32. Yasmin S, Zaka A, Imran A, Zahid MA, Yousaf S, Rasul G, et al. Plant growth promotion and suppression of bacterial leaf blight in rice by inoculated bacteria. PLoS One. 2016;11:e0160688.
33. White T, Bruns T, Lee S, Taylor J. Amplification and direct sequencing of fungal ribosomal RNA genes for phylogenetics. San Diego: Academic Press; 1990.

34. Weisburg WG, Barns SM, Pelletier DA, Lane DJ. 16S ribosomal DNA amplification for phylogenetic study. J Bacteriol. 1991;173:697-703.

35. Sivakumar T, Ambika S, Balakrishnan K. Biopriming of rice seed with Phosphobacteria for enhanced germination and vigour. Oryza. 2017;54:3469.

36. International Seed Testing Association (ISTA). Handbook on Seedling Evaluation. Switzerland: ISTA; 2003.

37. Association of Official Seed Analysts (AOSA): Seed Vigor Testing Handbook. Lincoln, NE., U.S.A.: AOSA; 1983.

38. Ellis $\mathrm{RH}$, Roberts $\mathrm{EH}$. The quantification of ageing and survival in orthodox seeds. Seed Sci Technol. 1981;9:373-409.

39. Mew TW, Misra JK. A manual of Rice seed health testing. Philippines: International Rice Research Institute; 2004.

40. Jones JB. Laboratory guide for conducting soil test and plant analysis. London: CRC Press; 2001

41. Sadh PK, Saharan P, Duhan S, Duhan JS. Bio-enrichment of phenolics and antioxidant activity of combination of Oryza sativa and Lablab purpureus fermented with GRAS filamentous fungi. Resour-Efficient Technol. 2017;3: 347-52.

42. Shangkuan Y-H, Yang J-F, Lin H-C, Shaio M-F. Comparison of PCR-RFLP, ribotyping and ERIC-PCR for typing Bacillus anthracis and Bacillus cereus strains. J Appl Microbiol. 2000;89:452-62.

43. Versalovic J, Koeuth T, Lupski JR. Distribution of repetitive DNA sequences in eubacteria and application to fingerprinting of bacterial genomes. Nucleic Acids Res. 1991;19:6823-31.

44. Hammer $\varnothing$, Harper DAT, Ryan PD. PAST: paleontological statistics software package for education and data analysis. Palaeontol Electron 2001;4. http:// palaeo-electronica.org/2001_1/past/issue1_01.htm. Accessed 1 Sep 2018.

\section{Publisher's Note}

Springer Nature remains neutral with regard to jurisdictional claims in published maps and institutional affiliations.
Ready to submit your research? Choose BMC and benefit from:

- fast, convenient online submission

- thorough peer review by experienced researchers in your field

- rapid publication on acceptance

- support for research data, including large and complex data types

- gold Open Access which fosters wider collaboration and increased citations

- maximum visibility for your research: over $100 \mathrm{M}$ website views per year

At BMC, research is always in progress.

Learn more biomedcentral.com/submissions 